\title{
Adı Vasfiye ve Dă̆ınık Yatak filmlerinin Carl Rogers'ın kişilik kuramı bağlamında incelenmesi
}

\author{
İrem Onur Akveran* \\ Pelin Erdal Aytekin*
}

\section{Özet}

Sinemanın geniş temsil alanı içerisinde kadının kişilik yapısı Yeşilçam sinemasında keskin bir değiş̧im yaşamış, bu değişim politika üzerinden; kültüre, sanata ve dolayısıyla bireye yansımıştır. Türkiye özelinde kültürel değişimin geniş kitlelere dokunduğu sanat alanı olarak Yeşilçam Sineması, kadın kişiliğinin temsil edilişi ve oluşumu bakımından belirleyici niteliklere sahiptir. 1980 öncesi Yeşilçam Sineması'nda yansıtılan kadın stereotipi iyi ve kötü oluş ile radikal bir yapıda iken; iyi oluş edilgen ve pasif, kötü oluş cinselliğ̈in sergilenişi ve açgözlülük gibi olumsuz özelliklerle temsil edilmiştir. 1980 sonrasında ise kadın kimliği ve kadının kişilik gelişimi bu ikilemden uzaklaşarak daha gerçekçi bir temsile dönüşmüş, bu dönüşüm kadının özgürleşmesi olarak yorumlanmıştır (Onaran, 1995: 15-16). Bahsedilen bu dönüşüm Atıf Yılmaz'ın 1980'li yıllarda çektiği 'kadın filmleri'nde görülmüş̧ür. Bu filmlerde kadın, diğer Yeşiçam filmlerinde olduğu gibi filmin merkezinde olmakla birlikte toplumsal cinsiyete bağh olarak kadına biçilen rolleri koşulsuz kabul eden, ev içine hapsolmuş kadından farklı bir kadın temsilini yansıtmıştır. 'Özgür kadın' temsili ile Müjde Ar, izleyicinin karşısına benzer karakterlerde ard arda çıkmıştır. Buradan yola çıkarak Müjde Ar'ın başrolünü oynadığı Atıf Yılmaz'ın Adı Vasfiye(1985) ve Dağınık Yatak(1984) adlı filmleri kadının özgürleşmesi olarak yorumlanan kadın temsilinin birer örneği olarak görülebilir. Bu nedenle Adı Vasfiye ve Dağınık Yatak filmleri, yeni özgür kadın temsilini psikoloji bilimi temelinde Carl Rogers'ın kişilik kuramı bağlamında tartışarak, yorumlayıcı yaklaşım ile ortaya konmaya çalışılmıştır.

Carl Rogers'ın kendini gerçekleştirmiş, 'kendi olmuş insan'ı tanımladığı kişilik kuramında Adı Vasfiye ve Dağınık Yatak filmlerinde oynayan Müjde Ar'ın temsil ettiği karakterin yorumlandı̆̆ şekliyle özgür olmadıkları, Carl Rogers'ın tanımladığı kendi olmuş insan özelliklerinin kişilik yapısı itibariyle karşılamadığı sonucuna ulaşılmıştır.

Anahtar Kelimeler: Carl Rogers, Toplumsal Cinsiyet, Feminizm, Kadın Filmleri, Kişilik.

*ORCID: 0000-0002-7790-9824 \& 0000-0002-1422-4860

E-mail: iremonr@gmail.com \& pelinerdala@gmail.com

DOI: 10.31122/ sinefilozofi.680707

Geliş Tarihi - Recieved: 01.15.2020

Kabul Tarihi - Accepted 07.05.2020 


\title{
A Review on the films Adı Vasfiye (Her Name is Vasfiye) and Dağınık Yatak (Unmade Bed) in the Context of Carl Rogers' Theory of Personality
}

\author{
İrem Onur Akveran* \\ Pelin Erdal Aytekin*
}

\begin{abstract}
Within the wide area of representation of cinema, woman's personality structure experienced a sharp change in Yeşilçam Cinema and this change was reflected on the culture, art and consequently individual over politics. As an area of art where cultural changes affect large masses in Turkey, Yeşilçam Cinema has distinctive qualities in terms of the representation and formation of woman's personality. While the stereotyped woman reflected in Yeşilçam Cinema before 1980 had a radical nature with being good and bad, being good was represented with passive characteristics, and being bad with negative characteristics such as the display of sexuality and greed. After 1980, woman's identity and personality development turned away from this dilemma into a more realistic representation; this transformation was interpreted as woman's liberation (Onaran, 1995: 15-16). This transformation was seen in the 'women's films' by Atuf Yilmaz in the 1980s. In these films, woman, as in other Yeşilçam films, is in the center of the film and reflects a different representation of a woman, who accepted the roles determined for women depending on the social gender without any condition and who was kept in the house. With the representation of a 'free woman', Müjde Ar consecutively appeared before the audience as similar characters. Hence, Adr Vasfiye (1985) and Dağınık Yatak (1984) by Atıf Yılmaz starring Müjde Ar in the leading role can be seen as the examples of the representation of the woman interpreted as the woman's liberation. Therefore, it was aimed to psychologically discuss the new representation of free woman in Adı Vasfiye and Dağını Yatak on the basis of Carl Rogers' theory of personality and present it with the interpretive approach.

The character represented by Müjde Ar in Adı Vasfiye and Dağınık Yatak was not as free as interpreted in Carl Rogers' theory of personality, where he defined the 'self-actualized', self-made human, and did not fulfill the personality structure of the self-made human characteristics defined by Carl Rogers.
\end{abstract}

Keywords: Carl Rogers, Gender, Feminism, Women Movies, Personality.

*ORCID: 0000-0002-7790-9824 \& 0000-0002-1422-4860

E-mail: iremonr@gmail.com \& pelinerdala@gmail.com

DOI: $10.31122 /$ sinefilozofi. 680707

Received - Geliş Tarihi: 15.01.2020

Accepted - Kabul Tarihi: 07.05.2020 


\section{Giriş}

Psikanalitik psikoloji'nin kurucusu ve temsilcisi olan Sigmund Freud (2010: 246), kişiliğin, en kaba, dürtüsel ve ilkel yapısı olan cinsellik ve saldırganlık içgüdülerinden doğan 'id', toplumun uygun gördüğ̈ü doğrular ve yanlışları yansıtan 'süper-ego' ve 'id'in kontrolünü sağlamaya çalışan, dengeleyici işleve sahip 'ego'nun oluşturduğu üç temel yapısının olduğunu ifade etmiştir. Bu üç temel yapıdan 'id' ve 'süperego' çatışma halinde iken, 'ego' dengeleyici bir yapıyı ifade eder. 'İd' ve 'süperego' arasındaki çatışma ve 'ego' nun dengeleyici işlevi bireyin davranışlarına yansıyarak kişiliği yansıtır.

Radikal davranışçı Burrhus Frederick Skinner davranışların çevresel uyarıcılarla açıklanması gerektiğini, bilimsel olarak incelenebileceğini, çevre tarafından belirlendiğini belirterek kişiliğin koşullanma ile pekiştirilen davranışların alışkanlıklar haline gelmesiyle oluştuğunu belirtir (İnan, Yerlikaya, 2010: 182). Psikanalitik yaklaşım içinde yer alan Harry Stack Sullivan ise kişiliğin, kişilerarası ilişkilerle oluştuğunu, sosyal çevre olmaksızın kişilik oluşturmanın mümkün olmadığını savunurken kültür, sosyal çevre, etnik köken, din, akıl sağlığı gibi farklılıklara rağmen insanlar arasındaki benzerliklerin daha fazla olduğunu vurgular. Sullivan'a göre kişilik sosyal güçler tarafından şekillenmekte, kişilerarası etkileşim sonrasında kurulan ilişki durumlarıyla oluşturulmaktadır (Burger, 2017: 178). Buradan hareketle kişilik kavramının soyut oluşu, kişilik kavramından ziyade kişiliği yansıtan davranışların bilimsel olarak ele alınabilmesi ve psikoloji biliminin kısa tarihi antik çağdan günümüze uzanan süreçte insan davranışlarının dinamiklerinin temellendirilmesini ve kişiliğin ortak bir tanımının yapılabilmesini engellemiştir.

Bunun yanı sıra mevcut tanımlardaki ortak öğelerle kişiliğe dair bir yapı oluşturulabilmek mümkündür. Bu ortak öğeler, ayırt edici olma, tutarlılık, yapılaşmış (örüntüsel halde olma) ve ilişki kurma biçimleri olarak karşımıza çıkar (Cüceloğlu, 2008: 404-405). Bu ortak öğeleri tanımına dâhil eden Cüceloğlu'na (2008: 404-405) göre: "Kişilik, bireyin iç ve dış çevresiyle kurduğu, diğer bireylerden ayırt edici, tutarlı ve yapılaşmış bir ilişki biçimidir." Dolayısıyla kişilik, insan davranışını, düşüncesini, duygusunu, fizyolojisini, çevreyle etkileşim biçimini zamansal ve mekânsal düzlemde ortaya koyan karmaşık bir kavram olarak değerlendirilebilir. Geniş bir araştırma alanını kapsayan kişiliğin çok sayıdaki tanımının varlığından bahsederken, birden çok kişilik kuramından bahsetmek de mümkündür.

Jean Mitry'nin Estetique du Cinema kitabında yer alan ifadesiyle “Sanat, aslında geçiş için bir yol işlevi görmektedir. Bu, özgürlüğe doğru giden bir yoldur. Bunu yalnızca sinema gerçekleştirebilir. Onun birinci unsuru ise yaşamın kendisidir!" (Bazin, 2011: 13). Dolayısıyla sinema yaşamın aynı zamanda gösterenidir. Yaşamı, sinema karakterlerinde ve bu karakterlerin kişiliklerinde bulmak mümkün olduğu gibi sinemanın kişiliği yapılandırma ve sunma gücüne sahip olduğu söylenebilir. 1980 sonrasında Atıf Yılmaz'ın çektiği filmlerde kadın karakterlerin özgürleştiği görüşü vurgulanmıştır (Onaran, 1995: 15-16). Bahsi geçen bu özgürleşmenin kişilik yansımalarında da gerçekleşip gerçekleşmediğinin incelenmesi bağlamında 'Adı Vasfiye'(1985) ve 'Dağınık Yatak'(1984) filmleri incelenmek üzere seçilmiştir. Her iki 
filmde de Müjde Ar’ın hayat verdiği kadın karakterlerin çoklu kişilik özellikleri çalışmaya uygunluğunu arttırmıştır.

\section{Kişiliğin Gelişimi: Carl Rogers'ın Kişilik Kuramı}

Psikoloji yaklaşımlarından biri olan hümanist yaklaşımda ise, insanın doğuştan getirdiği potansiyeli merkeze alarak kişilik kavramı açıklanmaya çalışılır. İyimser bakış açısına sahip bu yaklaşım, insanın özgür iradesinin olduğunu ifade eder (Yazgan vd., 2010: 293). Özgür irade seçim yapabilme, karar verebilme noktasında ele alınabilir. Buna bağlı olarak birey, davranışlarının sorumluluğunu alabilen, karar verici, değişim ve dönüşüme açıktır.

Hümanist psikolojinin öncülerinden Carl Rogers, Hristiyan dininin bireyin temelde günahkâr olduğu düşüncesi ve Freud'un 'id' olarak tanımladı̆̆ı, iradeyi yapısal olarak engelleyen ve 'id'in 'süper-ego' tarafından dizginlenemediği durumlarda ortaya çıkan olumsuz sonuçların, insanın özünde gerçekçi olmayan, hem kendisine hem de diğer insanlara zarar veren bir canlı olduğunun ve insanın kontrol altında tutulması gereken hayvani duyguların sahibi oluşunun eleştirisiz kabul edildiğini; insanın sevgi, güven, ait olma ve işbirliği gibi ihtiyaçlarının yok sayıldığını savunur (Rogers, 2011: 143). Rogers'ın insan doğasının irade dışı tüm davranışları ile oluşturduğu kişiliğe dair atıfların karşı çıktığı geleneksel söylem savunularına karşı tartışma getirecek nitelikte bir görüş sunmaktadır. İnsan kişiliğinin genel geçer kabulü Rogers için insana dair eksik ve niteliksel açıdan birçok özelliğin yok sayıldığı anlamına gelmektedir. Rogers psikanalitik psikolojinin savunduğu, çocukluk döneminde yaşanan takılmaların (fiksasyonların) ve bilinçdışı süreçlerin insanın tüm yaşantısına etki edeceği düşüncesine katılmaz.

Buna bağlı olarak Rogers'ın sürdürdüğü danışan merkezli psikoterapi çalışmalarından yola çıkarak oluşturduğu kişilik kuramında, insanın düşünce ve davranışlarını bilinçli bir şekilde değiştirebileceğini ifade etmiştir. İnsanı homo sapiens olarak ele aldığında, insanın özgür ve çarpıtılmamış bir farkındalığa sahip olduğunu, hayvanların ortak özelliği olarak duyular ve deneyimlerin bütününden pay aldığını, aynı zamanda şefkat duygusuna sahip, arzularını, üreme isteğini kontrol altında tutabilecek bir gerçekliğe dair potansiyelinin varlığını bilim dünyasına sunmuştur. İnsanın kontrol edilmesi, dizginlenmesi gereken bir canavardan fazlası olduğunu ve duyusal zenginliğinin yanı sıra özellikli bir merkezi sinir sistemine sahip olan insan fizyolojisinin kapsayıcılığını tartışmıştır (Rogers, 2011: 163). İnsanı hayvanlardan ayıran muhakeme, karar verme, duyuları değerlendirme, dil becerisi vb. özellikleri içinde barından merkezi sinir sistemi üzerinden insandaki potansiyelin ve donanımın önemine dikkat çekmekle beraber insanın ve insan kişiliğinin kontrolsüz ve edilgen yapısı olduğu varsayımına karşı çıkmıştır.

İnsanın, içgüdülerin yönettiği bir organizmadan fazlası olduğunu savunan Carl Rogers (1961), Maslow'un İhtiyaçlar Hiyerarşisi'nden etkilenmiştir. Kişinin kendini gerçekleştirme dürtüsünün doğuştan olduğunu, bu dürtünün annenin çocuğa sunduğu koşulsuz sevgi ile desteklendiğini, çocuğun belli koşullara bağlı olmadan 
sevgi ihtiyacını karşılayabilmesi durumunda olumlu benlik imgesinin geliştiğini ifade eder. Rogers'a göre çocuk, sevgi ihtiyacını belli koşullara bağlı karşılıyorsa, benliğinin ödüllendirilmeyen/sevilmeyen yönlerini baskılayacağını ve öğrendiği değerlere dair koşullar oluşturacağını ifade eder. Çocuğun sevgi ihtiyacının koşullara bağlı karşılanması, reddedilme korkusuyla çocuğun benlik gelişimini sekteye uğratır, kendini gerçekleştirmeye dair dürtüsünü sınırlandırır (aktaran Schultz ve Schultz, 2007: 680). Rogers'ın görüşü, insan doğasının dolayısıyla kişiliğin içsel olarak olumlu bir yapıya sahip olduğuna işaret ederken, acımasız, kontrolsüz ve yıkıcı davranışların dışsal etkilerle ortaya çıktığını, bu dışsal etkilerin insan doğasına aykırı bir yapıyı oluşturduğunu belirtmektedir. İnsanın kişiliğinin oluşum sürecinde kendini gerçekleştirme dürtüsünü sekteye uğratan engeli, koşullara bağlı karşılanan sevgi ihtiyacı üzerinden temellendirmiştir. Otoriter yapının yaygın egemenliğinde büyüyen ve gelişen birey, hayatta var olabilmek ve güç elde etmek için birçok davranış modeli geliştirir. Bunun anlamı otoritenin koyduğu kurallarla sınırlandırılmış bireyin, kendini gerçekleştirme alanının oldukça dar ve koşullara bağlı olduğudur.

Rogers (2011: 69), Kişi Olmaya Dair adlı kitabında kendini gerçekleştirme dürtüsü ve kişilik gelişiminin süreç içindeki gelişimini şu şekilde ifade eder;

(...) bireyin kişiliğini ve yaşamla kurduğu ilişkiyi daha olgun sayılabilecek bir yaklaşımla yeniden düzenleme isteğinde de görebiliriz. Buna isterseniz gelişme isteği veya kendini gerçekleştirme yönünde bir itki deyin, isterseniz de ileriye doğru hareket etmek deyin, bu yaşamın ana kaynağıdır ve son tahlilde, psikoterapi de her şeyiyle buna bağlıdır. Genişlemek, büyümek, özerk olmak, gelişmek, olgunlaşmak ve organizmanın sahip olduğu tüm kapasiteyi açığa vurma ve aktif hale getirme eğilimi... Bütün bunlar tüm canlılarda ve insan yaşamında görülen dürtülerdir. Bu dürtü, kabuk üzerine kabukla örttüğümüz psikolojik savunmaların altında gömülü olabilir; varlığını inkar eden süslü maskelerin ardında saklı olabilir; ama ben onun her bireyde var olduğuna ve ortaya çıkıp açığa vurulmak için uygun koşulları beklediğine inanıyorum.

$\mathrm{Bu}$ bağlamda birey, sınırlandırılmayan, engellenmeyen, yargılamayan ve şart koşmayan bir yapıda, kendini gerçekleştirme dürtüsü ile potansiyelini açığa çıkararak kişiliğini oluşturabilir.

Carl Rogers (1961) kişinin gerçekleşmesini istediği en büyük dileğinin kendi olmak olduğunu savunur. Psikolojik olarak sağl1klı kişiliğin - kendi olmuş bireyin özelliklerini tanımlamıştır. Rogers'a göre kendi olmuş bireyin özellikleri; deneyimlemeye (tüm yaşantılara) açık olmak, güvende ve özgür hissedeceği kişilerarası ilişkiler oluşturmak, her anı dolu dolu yaşama isteği, ne yöne isterse gidebileceği (duygu-düşünce ve davranışta özgürlük) hareket özgürlüğü, yüksek düzeyde yaratıcılık ve kendini gerçekleştirme ihtiyacıdır. Deneyimlemeye açık olan insan karşısına çıkan durumları önceden oluşturduğu kategorilere ve yaşantısal tecrübelere bağlı öngörülere göre reddetme veya kabul etme eğiliminde değildir (aktaran Schultz ve Schultz, 2007: 680). Rogers'ın insan doğası üzerinden yaptığı çıkarımlarlarla ideal kişiliği oluşturma süreci değerlendirildiğinde deneyimlemeye açık olmak, farkındalığı ifade etmektedir. Bireyin hem kendisine, hem bedenine dair farkındalığının artarak subjektif gerçekliğin 
dışına çıkabilmesini ve subjektif gerçekliğin dışından yaşantıyı anlamlandırmasını ifade etmektedir. Gerçeklik çok kapsamlı ele alınabilir, geliştirilen farkındalık kişiyi objektif gerçekliğe yaklaştıran olarak ele alınabilir. Bireyin her anı dolu dolu yaşama isteği, an'da kalmayı, an'ın hissettirdiği duygunun-düşüncenin farkında olmayı, bireyin duygularını ve olayı ya da durumu kavrayışı o anda olduğu biçimde anlamlandırmayı ifade etmektedir. İnsanlar geçmiş tecrübeleri ya da geleceğe dair düşünceleri nedeniyle an'1 yani "şimdi" yi kaçırırlar. Hareket özgürlüğü ise bireyin yaşantılarına dair artmış farkındalığıyla yaratııı, güvenilir ve yapıcı bir şekilde hayatı yaşaması anlamına gelmektedir. Psikolojik olarak olgunlaşmış olan ve seçme-seçilme özgürlügüunü kullanabilen bireyi ifade etmektedir. Tüm bu süreçler bireyin hem bilinç düzeyinde hem de bilinçdışında gerçekleşen içsel durumların ifadesi olarak ele alınabilir.

Rogers'ın görüşleri, bilim dünyası tarafından hemen kabul edilmemiş, ortaya attığ1 fikirler uzun zaman sonra dikkate alınarak, özellikle psikoloji alanında değişim yaratmıştır. Rogers'a gelen en büyük eleştiri insan doğasına dair çıkarımların çok iyimser oluşudur.

\section{Kişilik, Toplumsal Cinsiyet ve Toplumsal Yapı}

Kişilik batı toplumlarında ortaya çıkan, gelişen ve temellendirilen bir yapı olmakla beraber kültürlerarası değişiklik gösteren birçok özelliği de içinde barındırır. Kültürel beklentiler, gelenekler, yaşam tarzları, sosyal-politik koşullar, ekonomik yapı vb. birçok dinamik, kültürlere ait kişilik yapılarını doğrudan etkiler. Sadece kültürlerarası değil aynı coğrafyadaki alt kültürlerde bile kişiliğe dair değişkenlerin bulunduğu bilimsel olarak desteklenmiştir (Kağıtçıbaşı ve Cemalcılar, 2014: 328). Carl Rogers'ın kişilik kuramının ise bireyci (özerk), batı merkezli, geleneksel yapılar içindeki bireyden ziyade insanı merkeze alan ve potansiyeli ortaya koyma gayesini tanımlayarak oluşturulduğu söylenebilir. Rogers'ın 'kendi olmuş' bireyi tanımlarken ortaya koyduğu özgürlük, deneyime açıklık, yaratıcılık, kendini gerçekleştirme ihtiyacı, anı dolu dolu yaşama isteği, geleneksel toplum mekanizmalarının dışında, kişinin bireyselliğine odaklanan, modern toplumun merkezindeki insana ait ideal kişilik yapısını işaret etmektedir. Bu anlamda kişilik kuramları ve benliğin gelişimine dair tartışmaların ortaya çıkması hem bireyin gelişim süreçleriyle değerlendirilmiş hem de cinsiyet, kültür ve toplum yapılarıyla (sınıf, ırk, etnik köken vs.) kategorize edilerek tanımlanmıştır.

Ancak bu kategorizasyondan bağımsız evrensel değerler özellikle cinsiyetler arasındaki kimliğin gelişiminde belirleyici olmuştur. Biyolojik olarak cinsiyet (sex), fizyolojik bir tanımlama yaparken, toplumsal cinsiyet (gender), toplumun oluşturduğu kalıplar, kurallar ve davranış örüntülerine dair mekanizmaların çocukluktan itibaren öğrenilerek içselleştirilmesine neden olmaktadır. Bunun sonucunda bu mekanizmalar cinsiyetler üzerinden davranışları, rolleri tanımlayarak, cinsiyete dair beklentileri ortaya koyar (Connell, 1998: 255). Dolayısıyla toplumsal cinsiyetin evrensel ve kültüre özgü kalıp yargılar sağlıklı kişilik gelişimini sınırlandırmış, biyolojik cinsiyetin aslında cinsiyetten bağımsız kişilik özelliklerinin karşısında kültüre dair çerçeveleri olan, sınırlandırılmış, kişinin potansiyelini ortaya koymaktan uzak yapılar inşa ettiğinden 
bahsedilebilir. Toplumsal cinsiyetin içselleştirilmesi çocukluk çağlarından itibaren şekillenmekte, çocuğun oynayacağı oyun ve oyuncak, giyeceği kıyafet, tercih ettiği/edeceği renk dişil ve eril olarak etiketlenmiş bir şekilde sunulmaktadır (Dökmen, 2012:32). Buna bağlı olarak her alanda cinsiyet etiketi sarmalında büyüyen çocukların iletişim biçimleri, ilişki yapıları ve dolayısıyla kişilikleri de toplumsal cinsiyet rollerine göre gelişim göstermektedir, kişilik özellikleri de diğer yapılar ve kavramlar gibi eril ve dişil olarak kategorize edilmektedir. Örneklendirecek olursak erkeklerden beklenen davranışların temellendiği eril kişilik özellikleri; sert, tahakküm altına alan, denetleyici, kontrolcü, korkusuz vb. olurken, kadınlardan beklenen davranışların temellendiği dişil kişilik özellikleri; narin, kırılgan, fedakar sempatik vb. özellikler olarak sıralanmaktadır. Toplumun her alanında; ailede, okulda, sokakta bu dinamiklerle cinsiyetlendirilmiş kişilik yapıları bireylere kodlanmaktadır (Kümbetoğlu, 2010: 40). Anlaşılacağ1 üzere eşyalardan renklere, davranışlardan kişilik özelliklerine kadar cinsiyetlendirilmiş, kamusal alandaki roller de bu cinsiyetlendirmeye dâhil edilmiştir. Tüm toplumsal yapılar kadın ve erkekten beklenen davranışları talep ederken, bunun dışına çıkılması istenmeyecek şekilde bir yapılanmayı tarif eder.

Toplumsal cinsiyetin tarihsel olarak ortaya çıkışını Mine Tan (1979: 164) şu şekilde tarihlendirir. "Metallerin bulunuşu, hayvanların yetiştirilmesi, dokumacılığın ve tarla kültürünün gelişimi sonucu çıkan artı değerin aile mülkiyetine geçişi ile erkeğin ve kadının rolleri değişerek statüleri arasındaki eşitlik bozulmuştur.". Bu bağlamda kadının da bir mülkiyete dönüşmesi tartışması yapılabilir. Mülkiyete dönüşen kadının ikincil statüsü, değersiz olarak nitelendirilen işlere yöneltilmesi sonucunu doğurmaktayken, kadına ve malların tamamına sahip erkeğin önemli işlerin sorumluluğunu almasını ortaya çıkaracak yapıları şekillendirmiştir. Fatmagül Berktay (2000: 16), “Biyolojik cinsiyetten farklı olarak toplumsal cinsiyet, toplumsal ve kültürel olarak belirlenen ve içeriği toplumdan topluma olduğu kadar tarihsel olarak da değişebilen bir yapıya sahiptir" ifadesini kullanarak evrensel yapılar dışında toplumsal cinsiyet kavramının değişkenliğini vurgulamaktadır. Dolayısıyla bahsedilen roller ve kalıp yargılar niteliksel olarak zaman ve coğrafya içerisinde farklılık gösterse de cinsiyete dair ayrım evrenselliğini korumaktadır.

1980'lerin başlarında Amerika Birleşik Devletleri'nde başlayan ve oradan Avrupa'ya sıçrayan deregülasyon süreci, gerçekleşen özelleştirme yaklaşımıyla birlikte ekonomik, teknolojik, siyasi, aynı zamanda da sosyal/toplumsal alanının üzerinde de etkin bir rol oynamıştır (Çaplı, 2001: 34-35). Deregülasyona bağlı olarak yaşanan değişimin tüm dünyayı etkileyerek özelleştirme politikalarının farklı coğrafyalara yayıldığ1 düşünülebilir.

Marshall Berman Katı Olan Her Şey Buharlaşıyor adlı kitabında, bahsedilen bu regülasyonun sonuçlarını "modernleşme" kavramı içerisinde irdeleyerek özelleştirmelerle ortaya çıkan "modernleşen" insanın değişimini "Bu dünya-tarihsel süreçler, insanları modernleşmenin nesnesi olduğu kadar özneleri de yapmayı, onlara kendilerini değiştiren dünyayı değiştirmek için güç vermeyi, onları girdaptan çıkartıp bunu kendilerine mal ettirmeyi amaçlayan şaşırtıcı çeşitlilikte görüş ve düşünceyi 
beslemiştir." ifadesiyle açıklar (Berman, 2011: 29). Aynı zamanda 20. Yüzyılda "modernleşme" sürecinin tüm dünyaya yayıldığını dile getirir (Berman, 2011: 29). Anlaşılacağı üzere 1980'li yıllarda başlayan değişim Amerika Birleşik Devletleri'nden başlayarak ve sonrasında Avrupa'ya yayılmak üzere "modernleşme" ile kavramsallaştırılarak insanın özne olma sürecindeki dönüşümünü dile getirir.

Konuya Türkiye üzerinden yaklaşıldığında ise kimlik temsillerinin değişim ve dönüşümünün en belirgin dönemi 1980'li y1llar olduğu söylenebilir. Türkiye 1980'li yılları takip eden süreçte toplumsal bir temsil noktasından bireysel bir temsil noktasına doğru bir değişim yaşamıştır.

1980 darbesi sonrasında uzun zaman başlayıp devam eden neoliberal politikalar, kötü giden ekonomiye hayat vermek amacıyla arttırılmış, tam anlamıyla globalleşme amacıyla hızlanan özelleştirmeler toplumun her kesimini etkilemiştir. 12 Eylül 1980 sonrası kimlik politikaları ortaya çıkmış, kimlik politikalarının en güçlü, kalabalık ve sürdürülebilir mekanizmalarına sahip olanı, fark yaratanı kadın hareketi olmuştur (Ayata, 1998: 159-160). Kadınlar verdikleri eşitlik mücadelesinde eklemlendikleri 'sol' ideolojiden darbe sonrasında ayrılarak, kendi söylemleriyle bağımsız bir kitlesel harekete geçiş yapmışlardır.

1980 'den sonra politik yeniden yapılanma sadece ekonomiye değil sosyal hayata, kültüre ve sanata da yansımıştır. Sosyal hayat, kültür ve sanat, siyasi alandan ayrılmış, özerkliğini cinsel tercih, özel zevkler, bireyin özneyi oluşturduğu gündelik yaşam ve ertelenmiş, bastırılmış kişisel ihtiyaçlar üzerinden kurgulamıştır (Gürbilek, 2001: 10). Dönemin siyasi baskısı toplumsal açıdan başkaldırı öğelerini baskılamış olsa dahi bireyin kendiliğine dair bastırdığı tüm içsel mekanizmaların ortaya çıkışının tetikleyicisi konumunda düşünülebilir.

Nurdan Gürbilek, Vitrinde Yaşamak: 1980'lerin Kültürel İklimi'nde yaşanan dönüşümü 'özel hayat endüstrisi' olarak tanımlar ve şu şekilde açıklar;

Kuşkusuz bir "özel hayat endüstrisi"nden söz etmek mümkün. Bütün diğer alanlar gibi öznelliğin alanı da bir kez kitle iletişim araçlarınca kuşatılınca, bundan bazı mesleklerin çıkması kaçınılmaz. Artık özel hayat gazetecileri, özel hayat dergileri, özel hayat sineması, özel hayat romanları, özel hayat şarkıları var; bunlar kendi dillerini, kendi görüntülerini, kendi imajlarını yarattılar. Ama bu süreci yalnızca bir pazar arayışıyla, bir endüstriyle açıklamak mümkün değil. Çünkü bütün bunlar bir özgürleşme vaadiyle birlikte varoldular. 80'lerde insanların yabancılardan uzak tuttukları alanın kapıları bir an için başkalarına, yabancılara açılırmış, kamusal alandaki boşluk mahrem olanın kamusal bir değer kazanmasıyla doldurulurmuş gibi oldu. İnsanlar bunda bir özgürleşme vaadi bulmasalardı, öznelliğin alanı bu endüstriye bu kadar kolay açılamazdı. Basın ya da medya bu kadar başarılı olamazdı (Gürbilek, 2001: 55).

Özel hayat ile kamusal hayatın iç içe geçmesi, kamusal alan olan politik alanla mahrem alan olan ev içinin birleşmesi özel/mahrem ayrımının bir anlamda ortadan kalkmasına neden olmuştur. Bahsedilen özel hayat endüstrisi mevcut toplumsal değişimi kendi ihtiyaçlarına entegre ederek üretime sokmakla birlikte kamusal 
alandaki eril yapı ile ev içindeki dişil yapı üretilmiş sistemlerle toplumsal olana nüfuz etmiştir. Eril ve dişil karşıtlıklarla tanımlanan toplumsal alanın sınırlarının belli bir oranda eridiği söylenebilir.

\section{Toplumsaldan Bireye, Sinemada Kadının Özgürleşmesi}

"Özgürlük"; sadece insan değil tüm canlıları kapsayan, üzerinde hala düşünülen ve düşünülmeye devam edilecek olan, hakkında çokça yazılıp çizilen bir kavram olarak karşımıza çıkar.

Liberal geleneğin modern kapitalist sistem içerisindeki anlamıyla tanımlanmış özgürlük, toplum ya da devlet tarafından sınırlandırılmadı̆̆ sürece insanın özgür olduğunu ifade ederken özgürlüğü ifade eden şeyleri ihtiyaç ya da tercih olarak ele almıştır. Liberal geleneğin özgürlük tanımı, toplum içerisinde kendini gerçekleştirmenin toplum mekanizmaları içinde mümkün olmadığına, kişinin aldığı bireysel kararlar ve yaptığı seçimler üzerinde belirleyici bir rolü olduğuna işaret eder. Bu durumun karşısına Marksist özgürlük, topluluk halinde ve toplulukla ilişki içerisinde kişinin kendisini gerçekleştirmesini konmuştur (Cevizci, 2005: 1305).

Özgürlük ile bireyin özgürlüğü kavramsal olarak ayrışarak ele alınması kavramsal kargaşayı önlemede büyük oranda yardımcı olacaktır. Bireyin özgürlüğü üzerinden yapılan özgürlük tanımı; bireyin kendi iradesiyle karar alabilmesi, seçim yapabilmesi, yapılan seçimlerin sonuçlarına dair sorumluluğu alabilmesinin yanı sıra psikolojik, biyolojik ve toplumsal şartların üstesinden gelerek uygun davranışlarla eyleme geçmesi olarak ifade edilebilir (Cevizci, 2005: 1305). Bu noktada bireyin özgürlüğü hem kişisel hem de toplumsal olanla birlikte değerlendirilmiştir. Özgürlüğün tanımı ve tartışması, toplulukçu ve bireyci ikilemi, dünya düzeninin değişimiyle yeniden ve yeniden tartışılagelmiştir.

Türkiye'de 1980'den sonra değişim rüzgarı büyük oranda sinemaya da yansımıştır. Kadını merkeze alan 1980 sonrası filmlerde göze çarpan belirgin değişim bastırılan cinselliğin ortaya çıkışı, cinselliğin serbestliği olmuştur (Uluyağcı, 2002). 1980 sonrasında liberal politikalara eşlik eden bireyselleşme, kadın hareketinden güç alarak sinemada cinsellikle sunulmuştur. Bunun yanı sıra iyi ve kötü ikilemi olarak uçlarda yer alan kadın karakterlere giydirilen kişiliklerin daha gerçekçi bir temsile bürüdügüu, kadınların iyi oluş ve kötü oluş hallerinin belli koşullara bağlılığının sonlanarak yıkıma uğradığ1 söylenebilir. Ancak sinemadaki bu değişimin cinselliğin serbestliği üzerinden kurgulanışı 'özgürleşme' olarak adlandırılan yeni bir dönem yaratmıştır.

Bahsedilen değişimin sinemadaki etkisi, eski dönem yönetmenlerden Atıf Yılmaz’ın filmlerindeki cinselliğin serbestliği ve kadının özgürleşmesi temasıyla sunuluşunda görülebilir. Atıf Yılmaz, 1980 yılı sonrasında Türkiye'de yükselen feminist hareketin etkisiyle kadın sorunlarına ağırlık veren bir dizi film çekerek cesur 
bir yeniliği gösterime sunmuştur (Onaran, 1995: 15-16). Atıf Yılmaz filmleri, kadının sinemadaki temsilinde önemli dönüşümün kültürel sembolü olmakla birlikte çektiği kadın filmleri dönemin toplumsal koşullarıyla beraber değerlendirildiğinde, Bayrakdar'ın (2013) ifadesiyle “kadın karakterlerin geçirdiği bilinçlenme, bağımsızlaşma, kendi bedeninin ve hayatının kontrolünü ele alma süreci tarafından şekillendiğini söyleyebiliriz. Yeşilçam sinemasında utanç, düşkünlük ve günahla özdeşleştirilen yalnızca kötü kadınlara yakıştırılan cinsel arzular kadın filmleriyle farklı toplumsal kesimlerden sıradan kadınların yaşam deneyimlerinin bir parçası haline gelecektir" (Bayrakdar, 2013: 151). Bu bağlamda Atıf Yılmaz'in kadın filmlerindeki, ataerkil bakışın edilgen, pasif kadınını harekete geçirmiş, 70'lerin "iyi" kadın karakterlerini dönüştürerek "kötü" kadınlara giydirilen cinsel arzuları toplumun her kesiminden sıradan kadınların hayatının bir parçası haline getirerek sinemada sunmuştur (Bayrakdar, 2013: 151).

Atıf Yılmaz’ın kadının özgürleşmesi serüveninin ilk ürünü olan “Ah Güzel İstanbul" filmi, kadın temsilindeki değişimini ortaya koyan, filmin kadın başrolü Müjde Ar ile edilgen kadın harekete geçerek cinsel arzularıyla bütünleşmiş bir figür olarak beyaz perdede yerini almıştır (Özgüç, 2008: 200). Atıf Yılmaz'ın kadın filmlerinin çoğunun başrol oyuncusu olarak seyircinin karşısına çıkan Müjde Ar, oynadığı kadın karakterlerin yansıttığı günlük hayat deneyimlerinde, cinsel arzuları barındıran, tek gerçekliği anne olmak ve ev içi işlerle meşgul hayat pratiklerini barındıran yaşantılardan fazlasını ortaya koyan bir figür haline gelmiştir (Özgünç, 2008: 201). Müjde Ar'ın erotizminin sinemaya kattığı anlam ideal kadının dönüşümünün de başlangıcı sayılabilir. Geleneksel yapının kadına atfettiği edilgen, denetlenebilir, elinde olanla yetinen, sunulanı alan ve talepkar olmayan, fedakar, anlayışlı, iffetini koruyan, hayatının merkezinde mutlu bir yuva, aşık olduğu erkek ve sahip olduğu çocuklardan fazlasının bulunduğu Müjde Ar'ın temsil ettiği kadın karakterler sadece kadın seyirciyi değil kadın oyuncuların mesleki ve hayata dair duruşlarından farklı bir yerde konumlanmıştır. Müjde Ar'ın kurduğu ve konumlandığı bu yapı, hem toplumsal cinsiyet rollerinin dışında oluşu hem de deneyime açık bir kişiliğin temsil edilişi bakımından sinema sektöründe de kural yıkıcı ve düzen bozucu bir etkide bulunduğu şeklinde yorumlanabilir.

\section{Adı Vasfiye: Dört Farklı "Özgür" Kadın}

1985 yapımı Adı Vasfiye filmi, yazar olan Erol'un yazmak için konu arayışı sırasında Suna Sevim (Müjde Ar) adlı şarkıcının afişinin önünde durmasıyla başlar. Yazarın yanına daha sonra Emin karakteri gelir ve Suna Sevim' in aslında karısı Vasfiye olduğunu söyler ve Vasfiye ile olan hikâyesine başlar. Erol, Vasfiye'nin hikâyesini sırasıyla Emin, İğneci Rüstem, Kuyumcu Hamza ve Doktor Fuat'tan dinler. Her erkek karakter Vasfiye ile yaşadıklarını kendi gerçeğiyle aktarmaktadır. Dört farklı erkeğin dört farklı hikâyesi Vasfiye' nin güzel, alımlı ve işveli oluşunda ortaklaşır. Her erkeğin geçmişindeki anısında Vasfiye, çıplak bedeni, cinselliği ile arzu nesnesi olarak görülmektedir. 
Vasfiye karakteri dört farklı yaşantı içerisinde sunulmuş olmasına rağmen her karakterin belli kişilik özellikleri ortaklaşmaktadır. Her yaşantıda ortaklaşan kişilik özellikleriyle Vasfiye; sosyal, duygusal kararlılığı olan, sorumlu, değişikliğe açık, kendine yeterli, maceracı, dışa dönük olarak seyircinin karşısına çıkar. Bu özelliklerinin yanı sıra farklı bakış açılarıyla sunulmuş olsa dahi Vasfiye'nin beyaz perdeye yansıyan gruba bağlı, sosyal kabule önem veren, geleneklere bağlı kişilik yapısı silikleşerek kararlı, güven vermeyen ama kendine güvenen bir kişiliğe bürünür. Rogers' in kişilik kuramı temelinde bu dönüşüm değerlendirildiğinde, Rogers insan kişiliğinin değişimine dönüşümüne inanmış, bu noktada psikanalitik kuramcılara karşı çıkmıştır. İnsanın karar verme ve deneyimlemeye açı olma durumunu vurgulayan Rogers, kişiliğin değişimini savunmuştur. Vasfiye, deneyimlemeye açık, duygu, düşünce ve davranışta özgür oluş sonrasında toplumsal cinsiyet bağlamında kadını sınırlandıran, sosyal kabul ve geleneklere bağlı özelliklerinden kopmuş olarak ele alınabilir.

Emin'in karısı Vasfiye, Erol'un askerden dönmesini beklemeden evlenmek ister, Erol'un evlenmeye dair kaygıları ve ağabeyine olan güvensizliği Vasfiye'yi tatmin etmez, Erol'u cinselliğin yokluğu ile cezalandırarak evliliğe ikna eder. Vasfiye kocası askerdeyken Erol'un ağabeyinin tacizine uğrar ve Erol gelene kadar bekler, gelişiyle ağabeyden intikam alırlar. Vasfiye, köy meydanında eniştesinin yaptıklarını köy ahalisine duyurur, "namusunu" temizler, Erol'un ağabeyi kimsenin yüzüne bakamaz olur. Emin' in aktarımıyla sunulan karısı Vasfiye duygusal kararlılığı, dışa dönüklüğü ve geleneklere bağlı, sosyal kabulü önemseyen kişilik yapısı nedeniyle intikam alır. Bu intikam geleneklere bağlı ve sosyal kabule önem veren kişilik özelliklerinin yapısını bozan, hakkını arayan, sindirilemeyen bir izlenim oluşturarak bir karşıtlığı ortaya koymaktadır.

İğneci Rüstem'in yaşantısındaki Vasfiye'nin belirgin kişilik özellikleri bulunmamakta, cinsel bir obje, bir arzu nesnesi olarak sunuluşu vurgulanmaktadır. İğneci Rüstem aldatılan Emin tarafından öldürülmüş, Vasfiye can alan, yok eden, baştan çıkaran olmuştur. Vasfiye İğneci Rüstem'in anısında tekinsizliği ve karanlığı simgeler. Deneyime açık oluşu duygu ve düşünceden bağımsız sadece davranışsal olarak gözlemlenebilmekte, her anı dolu dolu yaşama isteğine dair bir çıkarım yapılamamakta, özgür hissedeceği kişilerarası ilişkilere rastlanmamaktadır. Vasfiye İğneci Rüstemin fantazisi olma dişında bir kişisel belirleyiciliğe sahip değildir. Cinsellikle bütünleştirilmiş Vasfiye, cinsellikle bütünleştirilen, can alan, tekinsiz, baştan çıkaran "kötü" nün arketipik temsili olarak değerlendirilebilir.

Vasfiye Doktor Fuat'ın görev yaptığı kasabada kuaför olarak seyircinin karşısına çıkar. Doktor Fuat Vasfiye'nin güzelliğinden etkilenir, Vasfiye'de Fuat'ın beğenisini fark eder ve ilgisine karşılık verir. Hasta olduğu gerekçesi ile Fuat'ı evine çağırır ve muayene sırasında çıplak bedenini teşhir eder, bedenin teşhiri Vasfiye'yi arzu nesnesine dönüştürür, Fuat ve Vasfiye'nin ilişkisi başlar. Vasfiye'nin sosyal kabule önem veren kişilik özelliği bu yaşantıda tamamen değişmiştir, toplumsal cinsiyet bağlamında sosyal kabule ilişkin normlardan bağımsız bir kadın figürü olarak yaşantısını sürdürmeye başlamıştır. Vasfiye diğer erkek karakterlerin anılarındaki 
Vasfiye'den farklı olarak üretime katılmakta, çalışıp parasını kazanmaktadır. Bu bağlamda Vasfiye'nin kamusal alanda yeni deneyimlere açık bir yapıda, romantik ilişkilerinde hem deneyimlemeye açık hem de duygu- düşünce ve davranışta özgür bir kişiliğe sahip bir şekilde yapılanmıştır. Ancak Vasfiye' nin kişilik özellikleri karşı cinsle olan ilişkileri boyutuyla vurgulanmakta, kendini gerçekleştirme kaygısından uzak bir yaşantısal örüntü göze çarpmaktadır.

Vasfiye anne değildir. Nilgün Abisel (2005: 296), Yeşilçam sinemasında kadın temsilinin aile ve annelik ile sınırlı olduğunu, kadının kendisini çocuklarına ve evine adadığı, bu sınırlar içerisinde şekillendiğini vurgulamaktadır. Anne olmayan, sınırsız hareket alanına sahip kadın figürü, yenilmeye, mutsuz olmaya, en sonunda ölmeye mahkumdur. Vasfiye'nin kadın kimliği anneliği dışarıda bırakmış, iyi ve kötü ikileminden uzaklaşarak Emin'in, Kuyumcu Hamza'nın ve Doktor Fuat'ın farklı bakış açılarıyla da olsa kalıp yargılar dışında kalarak gerçeğe yakın bir kadını temsil etmiştir. Ancak gerçeklikle arasındaki mesafenin kapanmasına rağmen anne oluş ile bir arada sunulmamıştır. Bu değerlendirme üzerinden yorumlamak gerekirse Vasfiye'nin özgürlüğü, hareket alanı, deneyime açıklığı ve radikal kararlar alması gibi kişilik unsurları anne olamayacak bir kadını temsil etmekte ya da annelerin varsayılan kişilik özellikleri ile ters düşmektedir. Kadının özgürlüğü annelik ile bağdaştırılamamıştır.

Vasfiye, erkekler tarafından atfedilen özellikleriyle seyirciye sunulan bir karakterdir. Vasfiye'yi Vasfiye olarak var eden kişilik özellikleri bulunmamakla birlikte, dört farklı erkeğin fantezileri üzerinden kurgulanan, ayırt edici nitelikte bir kişilik yapılanmasının bulunmadı̆̆ı, farklı yerlerde, farklı şekillerde muğlaklaşmış, olup olmadığı anlaşılamayan bir karakter olarak sunulmuştur. Vasfiyenin kişiliği her yaşantıda farklı şekillerde gösterilmekte, tutarlılıktan uzak bir belirsizlik içinde yer almaktadir.

\section{Dağınık Yatak: Güç̧lü Kadın Figür Meryem}

Dağııık Yatak (1984) filmi toplumsal cinsiyet bağlamında değerlendirildiğinde; metres olan Meryem'in üzerinde eril iktidarın baskısını görmek mümkün olmakla birlikte, kimliği, duyguları, özgürlüğü ve kişiliği baskın cinsel sahneler etrafında sunulmuştur. Filmde erkek, para ve güce sahip olan ve kadını satın alan bir karakter olarak kurgulanırken; kadın, bedeni ve cinselliği satarak hayatını sürdüren olarak kurgulanmıştır. Carl Rogers oluşturduğu kişilik kuramında kişinin potansiyelini ortaya çıkarmasının sevgi ihtiyacının koşullara bağlı karşılanıp karşılanmadığına bağlı olduğuna dikkat çekmiştir. Buradan yola çıkarak Meryem'in hayatında sevginin yanı sıra birçok ihtiyacının karşılanmasında ön şart cinselliğin, dolayısıyla bedenin erkeğe sunumu olarak ele alınabilir. Bu noktada beden ve cinsellik araçsallaştırılmış yapısıyla karşımıza çıkar.

Dağııık Yatak filminin ana karakteri olan Meryem (Müjde Ar) hikaye içerisinde, zengin erkeklerinin metresliğini yapan, birçok zengin erkeğin gözdesi konumunda, hakkında gazete haberleri yapılan bir kadın olarak yer alır. Film Meryem'in eski sevgilisinin Meryem'in evinin önünde intihar edişi ve bu intiharın gazete haberlerinde 
yer almasıyla başlar. Gazete okuyucuları bu haberi, Meryem'in felakete sürüklediği bir başka erkek kurban olarak yorumlarlar. Meryem bu intihar sırasında yeni sevgilisi zengin iş adamı Ferruh ile yatakta birliktedir. Meryem Ferruh ile beraber eski sevgilisinin mezarını ziyaret eder ve mezar başında "Kimseyi uğrunda ölecek kadar sermemelisin." diyerek aşka, sevgiye ve ilişkilere dair düşüncelerini dile getirir.

Meryem'in, duygusal kararlılığı olan, dışadönük, gözü pek, kontrollü, radikal, ödün vermeyen, gerçekçi, sakin ve soğukkanlı kişilik özellikleri vurgulanmıştır. Meryem'in bu kişilik özellikleri cinsiyetlere atfedilen kişilik özelliklerinin biraradalığını göstermektedir. Akıl ve duygunun karşıtlı̆̆ içerisinde hem duygusal nitelikleri hem de akla yani bilgiye dayalı kişilik özelliklerini birlikte barındırır. Bu kişilik özelliklerinin temsil edildiği en çarpıcı sahne Ferruh ile kurduğu diyalogda görülür. Meryem, "Benden geçmişimin hesabın isteme Ferruh, ya da bırak beni, hemen bırak!" diyerek tavrını koyar. Kontrol edilemeyen, karar veren kadını yansitır. Meryem bu diyalog ile hesap sormaya çalışan erkek iktidarına başkaldırır. Bu noktada Rogers'ın duygu düşünce ve davranışa dair hareket özgürlüğü Meryem'in kişiliğinde çarpıcı bir şekilde görülmektedir. Bu değerlendirmeyi ikinci bir sahne daha destekler: Meryem Ferruh ile kavgaya tutuşur ve "Yasaklarımı da kurallarımı da kendim koyarım Ferruh Bey! Bana kimse karışamaz!" diyerek erkek egemenliğini sınırlandırır.

Meryem karar verici, güçlü yanını ifade ederken "Ne kadar güçlüyse o kadar yalnız oluyor insan." diyerek yaşadığı duygusal boşluğu tanımlar. Bu noktada güce dair eril olarak tanımlanan kişilik özelliklerinin duygusal olarak yalnızlaştırdığını belirtir. Bunun yanı sıra Ferruh'a dair hisleri sorulduğunda "İçim bomboş Meryem Abla!" cevabıyla dertlenir, karşılayamadığı duygusal ihtiyaçlarını vurgulamakla beraber, kadının önünde güçlü olmak ile duygusal ve dolayısıyla zayıf olmak arasındaki keskin ayrımı işaret eder.

Özgür kadının temsili Meryem, katıldığı bir davette gördüğü komi İsmail'e âşık olur ve bu aşkla yeni bir farkındalık geliştirir. Meryem âşık olduktan sonra kendisini "kirli" hissetmektedir. Arkadaşı Sabahat'a duygularını açan Meryem'in “...Günün birinde bir de baktım buralara gelmişim. Hep erkeklerin canın yaktım durdum. Şimdi düşünüyorum da, upuzun bir intikam mıydı hayatım diyorum. Kendimi öyle kirli hissediyorum ki Sabahat abla!" ifadesi katı ve realist kişilik özelliklerinin, duygusal bir yapıya dönüştüğ ü şeklinde yorumlanabilir.

Tüm bunların ötesinde Meryem sık sık çocukluk anılarını hatırlamakta ve bu anılarda yoksul ve zor şartlarda yaşayan annesini, babasına ve babasının sevgilisine hizmet ederken görmektedir. Bahsedilen travmatik geçmiş yaşantılarda Meryem hem annesini hem de babasının sevgilisini kıyaslar ve babasının cinselliği barındıran dişil özellikleri ile temsil edilen sevgilisi ile özdeşim kurar, onu rol model olarak alır. Babası ve sevgilisinin keyif ve eğlence dolu yaşantısında Meryem, babasının sevgilisini taklit ederek, babasına ve sevgilisine eşlik ederek sevgi ihtiyacını kabul görme ve değer verilme üzerinden karşılar. Bu noktada Meryem'in sevgi ihtiyacı doğrudan koşullara bağlanmıştır. Bunun yanında aşk için geç kaldığına dair düşüncelerine eşlik eden hayal kırıklığı, Meryem'de bir farkındalık oluşturur. Meryem, tüm hayatını çocukluk 
döneminde yaşadığı travmalara bağlı olarak intikam üzerine kurmuştur. Güçlü, karar veren, edilgenlikten uzak kişilik yapısı aslında bir yanılsamadan ibarettir. Aynı zamanda Meryem'in yaşadığı aşk ilişkisi ve kontrol edemediği duygu olan aşk onu zayıflatmıştır. Ancak âşık olduğu İsmail'in bir sevgiliden çok ekonomik çıkara dayalı bir partnere dönüşmesi, Meryem'den sevgisini kendisine bir araba alarak kanıtlamasını talep etmesi Meryem'e büyük bir hayal kırıklığı yaşatır aynı zamanda beklentilerinin/umutlarının yok olmasına neden olur. Buna bağlı olarak Meryem yoğun hüznü, çaresizliği ve umutsuzluğuna rağmen karar verici ve güçlü yapısıyla İsmail'i terk eder. Bu noktada aşkına rağmen irade sahibi olarak perdeye yansır. Travmatik yaşantılarına ve kadını zayıflattığını düşündüğü duygularına rağmen Rogers'ın insanın duyusal zenginliği ve karar verme becerisine dair savını bu sahne desteklemektedir.

Filmde Meryem'in orgazm sahneleri uzun sürmekte ve bu sahnelerde kamera Meryem'in yüzüne odaklanmaktadır. Seyirci Meryem'in çıkardığı inleme sesleri eşliğinde yaşadığı hazzı da görür. Kadın orgazmı önemli bir gösterge olarak ele alınmalıdır. Cinsel birliktelik toplumsal cinsiyet rolleri açısından değerlendirildiğinde kadını araçsallaştıran, arzu nesnesine dönüştüren eril bir cinsel birliktelikle özdeşleşirken, kadın cinselliği iktidarın tahakkümü ve denetimi altında olmakla beraber, erkeğin talep ettiği ve erkeğin hayat pratiğinde düşünülür. Bunun yanı sıra bekaretin korunması, evliliğin ön şart olarak cinselliğin deneyimlenmesi toplumların öngördüğü kabullerden biridir (Karaman, 2017:126). Buna bağlı olarak orgazmin kendisi eril bir temsiliyet olarak günlük yaşamda ortaya konmaktadır. Meryem'in çarpıcı orgazm sahneleri cinsel açıdan da edilgen bir yapıda olmadığını göstererek, eril özelliklerden karar verici olmanın gücünü hissettirir. Cinselliğini özgürce yaşayan kadın olarak Meryem'i tanıtır. Bu çıkarımı Meryem'in âşık olduğu İsmail'in yatak odasına girerek cinselliği talep etmesi de destekler, kadın bedeninin teşhiri üzerinden sahne kurulsa dahi karakterler özelinde edilgen olan İsmail' dir.

Meryem'in evlilik koşulundan bağımsız yaşanan cinselliği, çok sayıdaki partneri, cinselliğinin ilişkilerdeki maddi karşıllğ̆ birarada değerlendirildiğinde Yeşilçam Sineması́nın iyi kadın kötü kadın ikileminin dışında kaldığı gözlemlenmiştir. Meryem, hem iyi kadın hem de kötü kadın özelliklerini bünyesinde barındırarak, aslında cinsiyetsiz olan ancak cinsiyetlere atfedilen kişilik özelliklerinin biraradalığını göstermektedir. Meryem'in kişiliği deneyimlemeye açık oluş, duygu düşünce ve davranışta hareket özgürlüğ ü ertafında şekillenmiştir. Ancak buna rağmen Meryem'in koşullara bağlı karşılanan ihtiyaçları Meryem'i 'kendi olmuş birey' olmaktan uzaklaştırır, sadece kendi olmaya dair bir arayıştan bahsedilebilir.

\section{Sonuç}

Kişilik kavramı, bireyin çevreyle kurduğu ilişkiler dâhilinde bireyi diğer kişilerden farklı kılan, sürekliliği olan bir yapı olarak tanımlanmasının yanı sıra bireyi özelliklerine göre başkalarınca değerlendiriliş biçimi olarak karşımıza çıkar. İnsanın duygu, davranış ve düşünce gibi temel özelliklerinin yansıtırken, çevresel koşullara bağlı olarak değişim ve dönüşüme uğrar, biriciktir. Buna bağlı olarak insanı iyimser bir 
yaklaşımla ele alan Rogers'ın kişilik kuramına göre insan, kendisini gerçekleştirmek, potansiyelini ortaya çıkarmak gayesindedir. Buradan hareketle Rogers, olumlu kişililik gelişimini 'kendi olmuş birey' tanımıyla bağdaştırır ve kendi olmuş bireyin özelliklerini ortaya koyar. Bu özellikleri Rogers, deneyimlemeye açık olmak, güvende ve özgür hissedeceği kişilerarası ilişkiler oluşturmak, her anı dolu dolu yaşama isteği, duygu-düşünce ve davranışta özgürlük, yüksek düzeyde yaratıcılık ve kendini gerçekleştirme ihtiyacı olarak ifade eder.

Kişiliğin gelişiminde önemli bir belirleyici olarak karşımıza çıkan toplumsal cinsiyet, biyolojik farklılıklardan bağımsız, toplumun oluşturduğu norm ve değerleri kadın ve erkek olmak üzere cinsiyet kalıplarına yerleştirerek benimsenmesi anlamına gelmektedir. Bu kalıpların kabulü hem cinsiyet kimliklerini hem de bu kimliklerden daha özel olan kişilikleri doğrudan ya da dolaylı olarak şekillendirmektedir. Bu yapıyla beraber hem kadının hem de erkeğin ev içinde de kamusal alanda da yapacağı işler, takınacağı tavırlar belirlenmiş, bu belirlenmiş kalıplar çocukluk çağından itibaren öğrenme ve içselleştirme gibi psikolojik süreçlerle nesiller boyu aktarmıştır. Kadın erkek dikotomisi üzerinden de çocukluk çağı itibariyle tüm kalıplar gibi kişilik özellikleri de kadın erkek cinsiyetlerine göre ayrılmakla birlikte kadın kişiliği özelinde bir sinırlandırma söz konusudur. Akıl ve duygu, etken ve edilgen gibi ikilikler kişilik özellikleri içerisinde cinsiyet yapılarını ortaya çıkararak bahsedilen dikotomi ile bir hiyerarşi oluşturmuş, bu hiyerarşi kişilik özelliklerinde de kendisini göstermiştir.

Sinema kadın temsilinde toplumsal yapının önemli bir sanat mecrası olarak karşımıza çıkmakta, kavramsal tüm yapıları somutlaştırarak yansıtmaktadır. 1980 sonrasında Türkiye'de yaşanan kültürel dönüşümün izlerini taşıyan sinema, özellikle kadının özgürleşmesi temasını Atıf Yılmaz filmleri ile seyirciye sunmuştur. Atıf Yılmaz’ın kadın filmlerindeki özgür kadın temsili Müjde Ar ile bedene bürümüş, özgürlük kadın cinselliği ve cinselliğin serbestliği ile özdeşleştirilmiştir. Dolayısıyla Müjde Ar karakterlerinin özgür birer kadını temsil ettiği vurgusu, kişilik özelinde değerlendirilmeye çalışılarak, Carl Rogers'ın kendi olmuş birey özellikleri üzerinden yorumlanmış, Müjde Ar'ın canlandırdığı Vasfiye ve Meryem karakterlerinin özgür kadını temsil ederken kendi olmuş bireyin özelliklerini taşıyıp taşımadığı tartışılmıştır.

Tüm bu değerlendirmeler ele alındığında Adı Vasfiye filmindeki Vasfiye karakteri erkeklerin gözünden anlatılmış, kimliği, varlığı ve kişiliği sinemanın metnin kuruluşu itibariyle muğlaklaşmış, varlığına dair gerçeklik belirsizleşmiştir. Anlatılan dört farklı kadının kişilik özelliklerinin değişkenliğinin yanı sıra Vasfiye, kendini gerçekleştirmekten uzak, hayatta varolma çabası cinselliğin serbestliği ile ilişkilendirilerek beyaz perdede gösterilmiştir. Bunun ötesinde Vasfiye erkek tarafından metalaştırılmış, arzu nesnesi olarak seyirciye sunulmuştur. Vasfiye'nin kişiliği deneyimlemeye açık oluşu ve hareket özgürlüğü cinsel deneyimin serbestliği ile ortaya konmuştur. . Dağınık Yatak filmindeki Meryem karakterinin kişiliği ise, kendi olmuş bireyin özelliklerinden deneyimlemeye açıklık, her anı dolu dolu yaşama isteği, duygu-düşünce ve davranışta hareket özgürlüğü değerlendiğinde özgür ve güçlü bir figürü temsil etmekte ancak bu güçlü ve özgür yapı kendini gerçekleştirmeye yönelik 
girişimlerde bulunsa dahi kadının potansiyelini ortaya çıkarmaktan çok kadının varoluşsal bir buhrana sürüklemiştir. Hem Vasfiye'nin hem de Meryem'in özgürlüğü ve gücü, her iki kadını duygusal bir yıkıma uğrattığı görülmektedir. Her iki karakterin yok edici, tehlikeli, güven vermeyen kişilik özellikleri seyirciye yansitılarak vurgulandığı söylenebilir. Özgür kadın felaketle eşdeğer tutularak, denetlenmesi gereken, korkulan özellikleri de barındırmaktadır. Bunun yanı sıra iki filmde de anneliğe dair bir atıf bulunmamakta, özgür kadının aile dışında temsil edildiğini düşündürmüştür. Aile dışında tutulan kadın kamusal alanda da sınırlı bir şekilde yer edinmiştir. Bu durum arafta olma halini akla getirmektedir. Çekirdek aile dişında Vasfiye'nin ve Meryem'in başka bir ortak özelliği köksüz oluşundadır. Filmlerde iki kadının ailesine dair birkaç kesit sunulmakta, sonraki yaşantılarda güvenli aile bağlarına rastlanmamaktadır. Anlaşılacağı üzere özgürleştiği ifade edilen kadın temsili ne toplumsal yaşamda ne bir mekana ne de yuva olarak adlandırılan özel alana aidiyetin dışında kalmıştır. Yeri belirsiz olan kadının özgürlüğü de belirsiz kılınmış, özgürlük kavramdan bağımsız olarak serbestliği çağrıştırdığı söylenebilir.

Her iki filmin sonunda kadın, bu belirsizlikle ve arafta bırakılmış olarak seyirciye sunulmuştur. Adı Vasfiye filminde Vasfiye'nin varlığının muğlaklığı, kişiliğin muğlaklığını da beraberinde getirirken, kadının kişiliğinin gerçekliğini de yarım bırakmaktadır. Dağınık Yatak filminde ise filmin sonunda Meryem'in güveni zedelenmiş, duygusal yıkıma uğramış hali deneyime açılığının ve hareket özgürlüğünün zorunlu ve doğal sonucu gibi gösterildiği ifade edilebilir. Kişilik üzerinde varoluşsal bir özgürleşme ödüllendirilenden ziyade cezalandırılan, umudun ve güvenin yitimine tekabül etmektedir. Kadının akıbeti her iki filmin sonunda da belirsiz bir şekilde seyirciye yansımıştır. Her iki kadın karakter, kendi olma yolunda seyretmenin yıkıcı sonuyla karşılaşmıştır. Bu nedenle kadının özgürleşmesine dair atıf sınırlı, koşullu ve şüphelidir.

İki filmde de ne Vasfiye'nin ne de Meryem'in yüksek düzeyde yaratıcılığına dair herhangi bir iz bulunmamaktadır. Vasfiye ve Meryem tamamen tüketici olarak konumlanmış, hayatın hiç bir alanında katkı sunan olarak gösterilmemiştir. Yaşama dair iz bırakacağı, kendisinden herhangi bir şey katacağı unsura rastlanmamaktadır. Yaratıcı olmaya dair herhangi bir katkısı olmayan bu iki kadının kendi hayatını biçimlendirme konusunda da planı bulunmamaktadır. Geleceğe dair ne bir hayale, ne de plana rastlanmaktadır. Yaşantıların tamamı an'a odaklı ya da kısa vadeli, gündeliktir.

Bu demek oluyor ki her iki filmde de kadın kişiliği Rogers'ın kuramı üzerinden yorumlandığında, kendini gerçekleştirme ve potansiyelini ortaya çıkarmaktan uzaktır. Kadın karakterlerin kişilikleri klasik Yeşilçam Sineması stereotiplerini karşılamamakla birlikte toplumsal cinsiyet bağlamında kendi olmuş birey olarak temsil noktasında eksiktir.

Toplumsal dönüşümlerin sanat alanına nüfuz edişi, gösteren aynı zamanda yansıtan olarak her sanat dalında kendisini tekrar ederek yeniden yapılanmaktadır. Feminist hareketin etkisiyle Yeşilçam Sineması ve sonrasında üretilen "Kadın Filmleri" 
hikayenin kuruluşunda özgürleşmeyi tam olarak taşıyamasa bile Yeşilçam Sinemasının kadınlarının kişilik özellikleri ile karşılaştırılabilir bir çok kişilik özelliği ortaya koymaktadır. O halde değişen ve insanı da dönüştüren toplumsal dinamikler üzerinden kronolojik olarak kişilik okumalarına imkan sağlamaktadır. Yapılan kişilik araştırmalarının güncel sanatsal yansımalarının sinema üzerinden yeniden ve yeniden üretildiği düşünülürse, kadın temsilleri bu kronolojiye göre değişimin göstereni olarak yeniden ele alınarak somut olarak örneklendirmeye imkan sağlamaktadır.

\section{Kaynakça}

Abisel, N. (2005). Türk Sineması Üzerine Yazılar, Ankara: Phoenix.

Arat, G. (2014). 1970-1980 Yillarn Arasında Türkiye'de Kültürel ve Sanatsal Ortam, İstanbul: Garanti Kültür.

Bayrakdar, D. (2011). Türk Film Araştırmalarında Yeni Yönelimler, İstanbul: Bağlam.

Bazin, A. (2011). Sinema Nedir?, İstanbul: Doruk.

Berktay, F. (2000). Tek Tanrılı Dinler Karşısında Kadın, İstanbul: Metis.

Berman, M. (2013).Katı Olan Her Şey Buharlaşıyor, İstanbul: İletişim.

Burger, J.M. (2016). Kişilik: psikoloji biliminin insan doğasına dair söyledikleri, İstanbul: Kaknüs.

Cevizci, A. (2005). Felsefe Sözlüğ̈̈.İstanbul. Paradigma.

Connell, R.W. (1998). Toplumsal Cinsiyet ve İktidar, İstanbul: Ayrıntı.

Cüceloğlu, D. (2008). İnsan ve Davranışı, İstanbul: Remzi.

Çaplı, B. (2001). Televizyon ve Siyasal Sistem, Ankara: İmge.

Dökmen, Y. Z. (2012). Toplumsal Cinsiyet Sosyal Psikolojik Açılamalar. İstanbul: Remzi.

Freud, S. \& Yardıml1, A. (2000). Metapsikoloji : haz ilkesinin otesinde, ego ve id ve basska yapitlar. Istanbul: Idea.

Gürbilek, N. (2001). Vitrinde Yaşamak. İstanbul: Metis.

İnanç, B.Y., Yerlikaya, E.E. (2010). Kişilik Kuramları, Ankara: Pegem.

Kağıtçıbaşı, Ç., Cemalcılar, Z., (2014), Dünden Bugüne İnsan ve İnsanlar, İstanbul: Evrim.

Karaman, M.İ. (2017). Sosyokültürel, Etik, Tibbi ve İslami Perspektiften Kız Çocuklarda ve Kadınlarda Sünnet. Anadolu Kliniği Tıp Bilimleri Dergisi, 22 (2), 125-130.

Kümbetoğlu, B. (2010). "Değgersizleştirme: Kadın Bedeninin Maruz Kaldığı Şiddet”, Dişillik, Güzellik ve Şiddet Sarmalında Kadın ve Bedeni, İstanbul: Ayrıntı, 39-61.

Onaran, A.Ş. (1995), Türk Sineması(II. Cilt), İstanbul: Kitle. 
Özgüç, A. (2008). Türk Sinemasının Kadınları, İstanbul: Agora.

Platon. (2013). Devlet. (C. Saraçoğlu, Çeviri). İstanbul: Bordo Siyah.

Rogers, C. (2011), Kişi Olmaya Dair, İstanbul: Okyanus.

Schultz, D., Schultz, S. (2007), Modern Psikoloji Tarihi, İstanbul: Kaknüs.

Tan, Mine, (1979), Kadın: Ekonomik Yaşamı ve Eğitimi, Ankara: Türkiye İş Bankası.

Ulıyağcı, C. (2002). 1980 Sonrası Türk Sinemasında Özgür Kadın İmgesi: Türkan Şoray ve Müjde Ar. Kurgu Dergisi, 19, 1-8.

Unsal, A. (1998). 75 Yilda Tebaa'dan Yurttaş,a Dogřu., Istanbul: Türkiye Ekonomik ve Toplumsal Tarih Vakfı.

https://www.academia.edu/11704762/12_Eyl\%C3\%BCl_1980_Askeri_Darbesi_Demok rasi ve T\%C3\%BCrk Bas\%C4\%B1n\%C4\%B1?auto=download Erişim Tarihi : 23.05.2019 